\title{
Social Capital in Agricultural Community Development: A Review
}

\author{
Muhammad Bello Ibrahim ${ }^{1}$, Salim Hassan ${ }^{2}$, Demba Sanyang ${ }^{3}$ \\ ${ }^{I}$ Department of Geography, Faculty of Social Sciences, University of Maiduguri, NE, NIGERIA. \\ Tel: +2347034486303, Email: mbellodk@unimaid.edu.ng \\ ${ }^{2}$ Department of Agricultural Technology, Faculty of Agriculture, University Putra Malaysia, 43400 Serdang, \\ Selangor, MALAYSIA. Tel: +60173355502, Email: salimhassan@upm.edu.my \\ ${ }^{3}$ Department of Agricultural Technology, Faculty of Agriculture, University Putra Malaysia, 43400 Serdang, \\ Selangor, MALAYSIA. Tel: +60182279059, Email: sanyang.demba@gmail.com
}

\begin{abstract}
Social capital has been focus of interest in considerable social science academic circles in recent years. Development of communities is a continuous process in order to sustain communities through utilizing their assets in a world that is increasingly becoming unpredictable and difficult in terms of togetherness and caring concerns for sustainability. The paper looked first at rural communities and the way social capital is built and utilized positively for community development despite lots of challenges. Social capital in agriculture was reviewed from rural community perspectives and seen as a motivating and gluing force for communitarian work that benefits the agriculture. The development of social capital as unseen capital in any society will provide the community members the force to forge ahead in whatever self-help endeavor their community resolved to undertake. The paper also considers the other side of the coin and looked at marginal community members that did not subscribe to social capital and became excluded from the beneficial collective actions of the majority. The paper lastly, posits that social capital in agricultural communities will go a long way in empowering community members to sustainably produce food and develop their communities.
\end{abstract}

Keywords: Agriculture, communities, community development, rural societies, social capital

\section{Introduction}

Development from the social perspective can be seen as a group's effort in making a continuous planned change to increase their wellbeing. Community development talks on all facets of human life. The traditional approach was more eradicating poverty and raising standards of living. Now there is a paradigm shift to address all facets of human life wrapping the concept in all approaches, either top-down or bottom-up dimensions changing various roles of people in the society. Social capital can be seen as the assets of the poor and their communities which they fall back to and help negotiate their way in an unpredictable and difficult world (Wong, 2007). Most communities that are endowed with diverse stock of civic associations and social networks will be stronger in controlling poverty and vulnerability over time, absence of social capital in a group can bring fear of being left 'out of the loop' in a committed networking so that social ties can be a blessing or blights giving all sorts of costs and benefits to the beholder (Narayan and Cassidy, 2001).

\section{Social Capital in Rural Societies}

Rural societies are rich in community work and exposes varying domains of social capital. In the rural setting social capital comprises of formal and informal systems of norms that encourages and promote cooperational trust in communities and wider rural societies. As an important capital in the society, it helps in accelerating the development of wellbeing and sociality, as it is not the exclusive property of individual but owned different social groupings as a characteristic of entire social system (Durston, 1998).

As social capital builds up in the social there is positive chances of good community development due to its provision of repair networks that mend and trends of economic and political disintegration (Mayer \& Rankin, 2002). If we perceived rural societies as having very strong social capital in all sectors of their life, then we can foresee a situation of improve bonding, linkage and bridging within the dwellers. All classes of capital in one way or the other contribute to the creation of wealth for sustainable growth and development, lubricating the social life of a community through 'civicness' which will enhance general productivity and facilitate agricultural practices within the community. A significant point of social capital here is that it is domiciled with specific individuals especially in the rural agricultural sector, and once mobilized for one purpose, can be conditioned for serving other customized purposes, for while natural capital decreases with continuous exploitation, social capital increases and accumulates with continuous usage (Roseland, 2000). In the rural areas, as observed in most developing countries, older and middle income groups had a sizeable portion of their livelihoods 
complemented by the occurrence of social capital leading to the growth of agricultural sector of most economies and contribute to the overall reduction of poverty accounting for 50 percent of government revenues in the 1960s, showing a symbiotic relationship between rural life, agriculture (Lawal and Atte, 2006; Ricci, 2012) and social capital making societies with high level of interpersonal trust, pro-social norms and interpersonal networks that emphasize reciprocity are more likely to experience positive economic, political and social development than those lacking these characteristics (Wakefield and Poland, 2005).

In her work on stronger families, Stone (2003) showed that social capital among families and communities provide a useful way of gluing people's lives and strengthening social relationships on an important part of sustaining families and promoting wellbeing within the larger community, this corroborates the work of Grootaert and Bastelaer (2002) on understanding and measuring social capital, where they observed that social structures and peoples' attitudes combined can increase the efficiency of collective action and community development. Agriculture is a vital component of every community and understanding social capital as a facilitator of the sector is pertinent in any community development endeavor so that workers and researchers alike will understand their relationship with a view of bringing out the best of outcomes, so much so that a construction of social capital endorsing the consequences of social capital development, could help community organizers build societies that in ways that truly promote agriculture (Ife, 1995; Wakefield \& Poland, 2005).

\section{Social Capital in Agriculture}

From the mid-1990s social capital has been the focus of considerable research (Wakefield \& Poland, 2005), with studies (Hawe and Shiell, 2000) suggesting that the concept has found applications in often existing relationships and initiatives that support and strengthen self- helping networks, build empowerment and community capacity, researchers said the concept despite being hotly contested and poorly defined (Woolcock, 1998) has penetrated communitarian, institutional and critical constructs with key premises bordering on benefitting entire communities, supportive to institutions and reinforcing individuals and groups within existing structures of domination (Putnam, 2000. Cohen \& Uphoff, 1977) showing its import in building sustainable endeavors in communities. Social capital today is allowing scholars, development workers and policy makers from different backgrounds a favorable playground for cooperation and dialogue (Brown, 1998) covering diverse communitarian, network, institutional and synergy views for propelling community development. Agriculture is an endeavor that cut across all the six continents of the world. Agriculture provides people with food from plants and animals. Societies have various ways of going about their indigenous agricultural practices as seen by Putnam (2000) that networks and associations bring similar people together, agricultural communities inclusive. In the rural settings of most developing countries, poor peasant farmers may have a close-knit and intensive stock of bonding social capital that leverage them to get on a collective work, unlike their counterparts in developed economies where bridging social capital is mostly used by the well-to-do rich farmers to 'get ahead' in their modernize farming practices, suggesting rural dwellers derived more from bonding and other domains of social capital. With the above view supporting a rational thinking, Ostron and Ahn (2003) sees it from a different angle, putting forward a collective action framework showing that the economic performances of societies from village to international communities will depend critically on how community members solve the problem of collective action, especially in agricultural sector as earlier pinpointed by Mortimore and Wilson (1965) in their work on Kano city, Nigeria where they described it as a closed-settled zone with people utilizing land around the city maximally through interaction of bonding and social cohesive domains of social capital within the peasant farmers to forge ahead in their agricultural practices. The place of collective action in community development has been addressed by Bourdieu (1986) and seen as a way of mobilizing community capital (human, built, cultural, financial, social, political and natural capital), a point that was later on emphasized by Ostrom and Ahn (2003) that social capital increases people's ability for collective work, even though some might argue that social capital, as a component of community capital, is an unseen capital which cannot be easily harnessed despite being embedded in interpersonal relationships and shaped by norms and practices in the community (Wong, 2007), but can serve as a glue of facilitating communal activities like farming.

In their work on social capital in agriculture, exploring the association between different forms of social capital and innovation in agriculture, from a sample of African countries, researchers studied instances and their work found mixed evidence that portrays some interesting findings. While structural social capital, especially in the form of connections beyond the village, is associated with more extensive adoption of innovations, the reverse is true for cognitive social capital that captured shared norms and trust within the local community, suggesting that social capital in agriculture needs more researches and study to maximize the benefits therein (Rijn, Bulte and Adekunle, 2012). Another angle of the occurrence of social capital in agriculture is its role and place when farmers and non-farming people live in the same community. Farmers might attempt to develop social capital or neighborly relations with non-farming neighbors in order to mitigate 
social constraints created by non-farming concerns within farming communities. Relationships from the nonfarming people, when it indicates support and tolerance of agriculture to be high, especially when non-farmers appreciate the existence of social capital with majority of the practicing farmers, it will lead to creating synergy between the two groups and subsequently leading to beneficial relationships for both the two components of the community, creating develop well-being and cordiality (Sharp and Smith, 2003). In this conception of social capital, the key issue in the community is not social ties per se, but rather the "scaling up" of these ties to form organizations that are economically effective for enhancing agricultural productivity within the various strata of the community.

Today agriculture has progressively changed from simple agronomy to multifaceted ways with alternative food systems (Albretcht et al.,2013) in efforts to feed persistent increasing population of humans as regards natural resources' scarcity and efforts for agricultural and rural development, as highlighted in the work of Medugu (2006) where he observed that for agriculture to be successful, rural development has to be addressed in order to enhance sustainable wellbeing of rural dwellers coupled with sustained physical, socioeconomic improvement of the people, a fact which calls for giving attention to developing social ties that will promote 'we' feeling within guilds of farmers. This view was later on highlighted and supported in the work of Peet and Hartwick (2009) where they say that sustainable development means making a better life for everyone, providing a powerful and emotive ideal that appeal to the best in people, especially those associated with agricultural productivity. All these arguments will hardly be achieved in any community where social capital is lacking or operating at very low ebb, therefore any agricultural population will certainly prosper with a high degree of social capital in their community (Kretzman \& McKnight, 1993).

In socio-economic organizations, social capital is important to their community development; as such it cannot be conceived in isolation from socio-economic structures bringing increased social bonds and trust leading improved equity in the society, including the unseen nature of social capital degree therein. Seeing it from another angle, Fukuyama (2000) sees a 'dark side of social capital' that excludes those who are unable or unwilling to conform to community's norms and values leading to 'naming, blaming and shaming' of those excluded and not minding their sensitivities to the way they are embedded in the social structures, thus pointing out that community workers have to attempt to build social capital and not to compromise equity and social justice, the society has to be caring and catering for the various shade of capabilities and sensibilities of the community members (Poland, 2000). From these groupings and social formations, a mosaic of locally rooted practices and initiatives that promotes and enhances agriculture in efforts to fight food shortages will be improved due to the community supported agriculture, where through the presence of social capital, a viable business arrangement in which farmers and consuming community members negotiate their respective positions across a more beneficial divide (Freidberg and Goldstein, 2010). The community of farmers, in support of this earlier view, as put forward by Durston (1998) who maintained that social capital is strengthened each time it is activated within different circles as positive experiences of trust in economic matters and success in common cause lead to greater trust and greater civic commitment, because it is not the exclusive property of individual but owned by social grouping and seen as a characteristics of the entire social system. This point shows that social capital is both a private and public good, with benefits accruing not only to those persons making the investments in social networks and groupings but also to the wider community in the form of positive externalities from farming communities to the larger society (Florida and Rousseau, 2005). Farming communities are important units in rural community development and locus of action, that in an increasing mechanized productive and fragmented world according to specializations, the search for a source of ensuring food production, no matter the techniques, is important and the presence of social capital will go a long way in boosting a favorable setting for socially equitable friendliness within the society for sustainable agricultural practices, that will lastly generate better quality for life (Bridger \& Luloff, 2001; Salau \& Atta, 2012). In most rural settings, social capital is seen as facilitating community self-help, allowing communities to easily work together to solve their collective problems and determine their development, as opposed to urban places where community self-help is persistently being eroded due to a lot of factors, therefore the building of social capital in our farming communities will be seen as an important facilitator with positive outcome in efforts for sustainable community development (Christenson \& Robinson, 1989).

\section{Conclusion}

Social capital concept is witnessing an increasing usage in circles of community development work and researches, and within its various constructions has been linked to agriculture and farming communities. In international for a of development, for instance, the term is already well used by the World Bank, operating a very rich website for those interested in understanding and applying the concept for sustainable development in all types of societies (http://www.worldbank.org/poverty/scapital/index.htm, accessed Nov/Dec 2015). Most agricultural communities are geographically defined and this facilitates through the locality development approach, emphasizing the importance of self-help and mutual aid in building better communities within 
identified areas and occupations. In this paper, we have discussed the relationship between social capital and agriculture, with specific focus on community development. We recognize the importance of community connections and its resultant social capital emergence, leading us to show how these societal ties and norms will be resourceful in making a community to develop, an explanation that recognizes the potential positive advantages of social capital development, which could help community development workers and society members build communities that truly promotes agriculture in the rural areas.

\section{References}

[1] Albrecht, C., Johnson, R., Hamann, S., Sneyd, L., Ohberg, L., \& CoDye, M. (2013). Toward alternative food systems development: Exploring limitations and research opportunities. Journal of Agriculture, Food Systems, and Community Development, 4(1), 1-9.

[2] Bridger, J.C., and Luloff, A.E. (2001). Building the sustainable community: Is social capital the answer? Sociological Inquiry. Vol.71, 4 .

[3] Christenson, J. A., \& Robinson, J. W. (1989). Community development in perspective. Iowa State University Press.

[4] Cohen, J. M., \& Uphoff, N. T. (1977). Rural development participation: concepts and measures for project design, implementation and evaluation.Monograph Series, Rural Development Committee, Cornell University, (2).

[5] Durston, J. (1998). Building social capital in rural communities. LASA, Chicago IL.

[6] Feidberg, S., \& Goldstein, L. (2010). Alternative food in the global south: reflections on a direct marketing initiative in Kenya. Journal of Rural Studies. Doi:10.1016/j.jrarstud.2010.07.003.

[7] Florida, R., \& Rousseau, D. (2005). Building and bonding: a multidimensional approach to regional social capital. Martin Prosperity Trust, Joseph L. Rotman School of Management, University of Toronto.

[8] Fukuyama, F. (2000). Social capital. In L.E. Harrison, \& P. Samuel (Eds), Culture matters: how can human values shape human progress (pp. 98-111). New York: Basic Books.

[9] Grootaert, C., \& Van Bastelaer, T. (Eds.). (2002). Understanding and measuring social capital: A multidisciplinary tool for practitioners (Vol. 1). World Bank Publications.

[10] Hawe, P., \& Shiell, A. (2000). Social capital and health promotion: a review. Social Science \& Medicine, 51, 871-885.

[11] Ife, J. (1995). Community Development. Melbourne: Longman.

[12] Kretzman, J., \& McKnight, J. (1993). Building communities from inside out: a path toward finding and mobilizing a community's assets. Evanston, IL: Center for Urban Affairs \& Policy Research, Neighborhood Innovations Network, Northwestern University.

[13] Lawal, A.M. \& Atte, O.A (2006). An analysis of agricultural production in Nigeria. African Journal of General Agriculture. Vol 2 (1)

[14] Mayer, M. \& Rankin, K.N. (2002). Social Capital and (community) Development: a north / south perspective. Antipode 34(4) 804808.

[15] Medugu, I.N. (2006). Achieving sustainable agriculture in Nigeria: a land-use policy perspective. Shibura Institute of Technology Japan.

[16] Mortimore, M. and Wilson, J. (1985). Land and people in the Kano Close-Settled Zone. Occasional Paper No. 1, Department of Geography, Zaria: Ahmadu Bello University.

[17] Narayan, D., Cassidy, M.F.,(2001). A dimensional approach to measuring social capital: development and validation of a social capital inventory. Current Sociology. Vol. 49(2) 59-102

[18] Peet, R. and Hartwick, E. (2009). Theories of development: Contentions, Arguments, Alternatives. Guilford Press, New York.

[19] Pennington, M., \& Rydin, Y. (2000). Researching social capital in local environmental contexts. Policy and Politics, 28, 233-249.

[20] Poland, B. (2000). Social capital, social cohesion, community capacity, and community empowerment: variations on a theme? In B. Poland, L.W. Green, \& I. Rootman (Eds). Settings for health promotion: linking theory with practice. Newbury Park, CA: Sage.

[21] Putnam, R.D. (2000). Bowling alone: the collapse and revival of American community. New York: Simon and Schuster.

[22] Ricci, L. (2012). Peri-urban livelihood and adaptive capacity: urban development in Dar Es Salaam. Consilience: The Journal of Sustainable Development, 7(1), 46-63.

[23] Saegert, S., Thompson, J.P., \& Warren, M.R. (Eds). (2001). Social capital and poor communities. New York: Russel Sage Foundation.

[24] Salau, E. S., \& Attah, A. J. (2012). 'A socio-economic analysis of urban agriculture in Nasarawa State, Nigeria. PAT, 8(1), 17-29.

[25] Sharp, J. S., \& Smith, M. B. (2003). Social capital and farming at the rural-urban interface: the importance of nonfarmer and farmer relations.Agricultural systems, 76(3), 913-927.

[26] Stone, W. (2003). Bonding, bridging and linking with social capital. Stronger families learning exchange bulletin, 4(1), 13-16.

[27] Van Rijn, F., Bulte, E., \& Adekunle, A. (2012). Social capital and agricultural innovation in Sub-Saharan Africa. Agricultural Systems, 108, 112-122.

[28] Wakefield, S.E.L and Poland, B. (2005). Family, friend or foe? Critical reflections on the relevance and role of social capital in health promotion and community development. Social Science \& Medicine, 60, 2819-2832.

[29] Wong, S. (2007). Exploring ‘unseen' social capital in community participation. Amsterdam University Press. 